\title{
Solid palm oil as poultry feed and growth media of Black Soldier Fly (BSF) larvae
}

\author{
Ermin Widjaja ${ }^{1 *}$, and Bambang Ngaji Utomo $^{2}$ \\ ${ }^{1}$ Indonesian Center for Agricultural Technology Assessment and Development, Jl. Tentara Pelajar \\ No.10, Bogor 16114, Indonesia \\ ${ }^{2}$ Indonesian Research Center for Veterinary Science, Jl. RE. Martadinata No. 30 Bogor 16114, \\ Indonesia
}

\begin{abstract}
The poultry industry in Indonesia has big challenges due to the high price of feed. It is important to use local feed resources as an alternative to reduce production costs. The local feed that has big potential is solid palm oil. The objective of this study was to determine the potential of solid palm oil as a source of protein for poultry feed, and as the growth media of Black Soldier Fly larvae (BSF). The research was conducted to grow BSF solid palm oil as a growth media for 20 days. Solid palm oil was analyzed its nutrient content before and after it was used as the growth media of BSF. The BSF was also analyzed its nutrient content. The results showed hat the content of fresh solid, BSF, and solid used for BSF growth media ware energy $3336.6 \mathrm{kcal} / \mathrm{kg}, 4773.2 \mathrm{kcal} / \mathrm{kg}, 1201,8 \mathrm{kcal} / \mathrm{kg}$, crude protein $13.55 \%, 29.05 \%, 8.03 \%$, crude fat $12.46 \%, 33.72 \%, 2.62 \%$, and crude fiber $15.47 \%, 11.49 \%, 6.68 \%$. The research results showed that solid palm oil contains nutrients that are good for poultry feed and for the growth of BSF larvae.
\end{abstract}

Keywords: Solid palm oil, BFS larvae, growth media, Nutrient, Feed, Poultry

\section{Introduction}

The oil palm plantation industry in Indonesia is growing rapidly from year to year. The industry produces 2 types of oil, namely crude palm oil (CPO) and Palm Kernel Oil (PKO). As for the process of CPO production, by-products are produced, one of which is solid palm oil. Solid palm oil is interesting to discuss because it has the potential as an alternative source of animal feed. Currently, these by-products have been widely used, especially by private of livestock breeding and fattening engaged in the oil palm plantation industry. There is no report on its use other than as animal feed. By palm oil mills, these by-products are disposed of in the garden to be used as fertilizer. The advantage of using solid palm oil is to help overcome environmental pollution due to the stench it causes.

\footnotetext{
* Corresponding author: erminwidjaja02@gmail.com
} 
Solid palm oil was first introduced by [1] as animal feed, and now it has been widely used and improved in quality by adding other mixed materials for palm oil waste [2]. As cattle feed, it can increase productivity $[1,5,6]$ and the potential to be developed as poultry feed ingredients $[3,4]$. As a source of feed ingredients, solid palm oil has a tremendous potential; they are abundant (can reach 100 tons/day), cheap because they are waste, good quality as feed ingredients, and continuous availability [6]. On the other hand, it has disadvantage that it is easy to go rancid because it still contains around 1.5\% CPO [1] and within 3-4 days, larvae which is known as Black Soldier Fly (BSF) larvae appeared. Fortunately, it turns out that these larvae have the potential as a high-quality, efficient and sustainable alternative protein source for poultry [7]. Various studies of BSF larvae as a source of animal feed protein are being carried out $[7,8,9,10]$.

Various growth media were made to grow BSF or Hermetia illucens larvae [11-12]. Various growth media that have been tested include palm kernel cake $[13,14,15]$, organic waste from industrial and urban waste [16], cow dung [17], chicken manure, tofu dregs [1819], tuna processing waste [11-12], etc. BSF larvae are easy to grow on various media because they have a wide $\mathrm{pH}$ tolerance [14]. Thus, BSF larvae are the mainstay in generating alternative feed supply independently by utilizing industrial waste through a bioconversion process, converting organic waste into simple compounds. The ability of BSF larvae to perform bioconversion is due to the presence of several bacteria in its digestive tract [12]. BSF larvae have great potential as an alternative to prove protein sources. Therefore, research on alternative feed resources has attracted the attention of many researchers, considering that spread reaches $60-70 \%$ of the total production cost [20-21] The purpose of this study was to see the potential of solid palm oil as a source of poultry feed before and after bioconversion by BSF larvae and the ability of solid palm oil as a growth medium for BSF larvae.

\section{Materials and methods}

\subsection{Material}

This research material was a solid waste of palm oil obtained from one palm oil mill in West Kotawaringin Regency, Central Kalimantan. Solid waste of palm oil was spread on a tarpaulin and left in the open air but given a roof not exposed to rainwater.

\subsection{Method}

The fresh solid palm oil that had just arrived from the mill was analyzed for its nutritional value. Solid palm oil that had been spread out on a tarpaulin was observed for 20 days on the growth of BSF larvae by going back and forth because the larvae were hiding in a pile of solid palms.

The weight of the solid palm oil was weighed before and after the growth of BSF larvae. In addition, solid palm oil after being overgrown with larvae was checked for nutritional content, and BSF larvae was analyzed for its nutritional content.

\section{Results and discussion}

\subsection{Solid palm oil}

The solid nutrient examination of fresh palm oil compared with solid palm oil after being used as a growth medium for BSF larvae is presented in Table 1. 
Table 1. Solid nutrient content before and after the growth of BSF larvae

\begin{tabular}{|l|c|c|}
\hline Nutritional content & Fresh solid palm oil & Post growth BSF \\
\hline Dry matter (\%) & 88.98 & 90.02 \\
\hline Energy kcal/kg & 3336.6 & 1201.8 \\
\hline Crude protein (\%) & 13.55 & 8.03 \\
\hline Crude fat (\%) & 12.46 & 2.62 \\
\hline Crude fiber (\%) & 15.47 & 6.68 \\
\hline Ash (\%) & 20.46 & 11.42 \\
\hline
\end{tabular}

The results showed that bioconversion had occurred, which was indicated by changes in the nutritional content of solid fresh palm oil with solid palm oil after growing BSF larvae. The nutritional value of solid palm oil after being overgrown with larvae decreased. This is in line with that reported by [11-12].

The emergence of BSF larvae naturally without having to place BSF eggs on solid palm oil media is one of the advantages of solid palm oil as a growth medium for BSF larvae. It is enough to wait 3-4 days for BSF larvae to appear in the solid palm oil. At a longer time, the more larvae was produced and solid palm oil weight as growth medium was decrease. BSF larvae were produced by $30 \%$ of the weight of the media on the 20 th day of harvest with larvae length of $15-23 \mathrm{~mm}$. On day 20 solid media produced larvae as much as $30 \%$ of the weight of solid media with a length of $15-23 \mathrm{~mm}$. According to [22], the growth of larvae (maggots) is primarily determined by the growth media, and not all media can be used as a place to lay eggs for BSF flies (Hermetia illucens). Thus, solid palm oil is an excellent alternative growth medium for BSF larvae.

Solid palm oil growth media is efficient, does not require significant capital, and is very easy to implement by farmers. Moreover, its abundant availability makes solid palm oil a perfect growth medium for BSF larvae. Apart from being a growth medium, solid palm oil itself is a potential animal feed ingredient. The need for nutritional value for cows, especially protein, for example, concentrate feed for Brahman Cross cattle contains $13.76 \%$ crude protein [23], which can be met from solid palm oil given singly [1-5] or in the form of formulation with the addition of other feed ingredients [2]. It can even be used for mixed ingredients (formulations) of poultry feed [3-4], as we can see in Table 2.

Table 2. Utilization of solid palm oil as animal feed

\begin{tabular}{|c|c|c|c|c|}
\hline \multirow[t]{2}{*}{ No } & \multirow[t]{2}{*}{ Feed formulation } & \multicolumn{2}{|c|}{ Description } & \multirow[t]{2}{*}{ Referensi } \\
\hline & & Jenis ternak & Research Results & \\
\hline 1 & Solid palm oil+natural grass & PO Cattle & ADG: , $77 \mathrm{~kg} /$ tail/day & 1 \\
\hline 2. & Solid palm oil+natural grass & $\begin{array}{l}\text { Local Cattle } \\
\text { (small type) }\end{array}$ & ADG: $0.47 \mathrm{~kg} /$ tail $/$ day & 5 \\
\hline 3. & $\begin{array}{l}\text { Solid palm oil+palm } \\
\text { fronds+BIS }+ \text { molases }+ \text { mineral }\end{array}$ & BX cattle & ADG: $0,99 \mathrm{~kg} /$ tail $/$ day & 2 \\
\hline \multirow[t]{3}{*}{4.} & \multirow[t]{3}{*}{$\begin{array}{l}\text { Solid palm oil+fish } \\
\text { flour+BIS+corn+soybean } \\
\text { meal+CPO+mineral }+ \text { ZnCO3 }\end{array}$} & \multirow[t]{3}{*}{ Broiler } & $\begin{array}{l}\text { - Final live weight up to } \\
8 \text { weeks of age: } 2507.6 \\
\text { grams }\end{array}$ & 3 \\
\hline & & & $\begin{array}{l}\text { - Increase in live weight } \\
2,464.4 \text { grams }\end{array}$ & 3 \\
\hline & & & - Carcass: $65,89 \%$ & 4 \\
\hline
\end{tabular}

As for solid palm oil, after larvae are overgrown, although the nutritional value of the main protein has decreased, it is still suitable to be used as animal feed, especially for cattle, by adding other mixed ingredients such as palm kernel cake, bran, etc. The crude protein content is relatively not inferior to superior grass. 
Another factor that is thought to affect solid palm oil, which is rapidly grown by BSF larvae, is the nutritional content, according to [20]. Central Kalimantan, especially in the West Kotawaringin Regency where this research is located, has a maximum temperature of $32.60{ }^{\circ} \mathrm{C}-37.20{ }^{\circ} \mathrm{C}$ and average humidity of $86.05 \%-87.95 \%$ [24]. According to [25], the optimum temperature for BSF growth is $30^{\circ} \mathrm{C}-36{ }^{\circ} \mathrm{C}$. BSF larvae cannot survive at temperatures less than $7{ }^{\circ} \mathrm{C}$ and more than $45^{\circ} \mathrm{C}$. According to [26], the humidity was also reported to affect the egg-laying capacity of BSF flies. About $80 \%$ of female flies lay eggs at humidity conditions of more than $60 \%$, and only $40 \%$ of female flies lay eggs when humidity conditions are less than $60 \%$. Based on this reference, the temperature and humidity in West Kotawaringin Regency are ideal for the growth of BSF larvae.

\subsection{BSF larvae}

Based on the nutrient content of fresh solid palm oil and BSF larvae, it showed that BSF larvae could convert solid biomass (percentage) as presented in Table 3. There was an increase in nutritional value for crude protein, crude fat and energy. Meanwhile, crude fiber decreases its nutritional value.

Table 3. The nutritional value of fresh solid palm oil and BSF larvae it was produced

\begin{tabular}{|l|c|c|c|}
\hline Nutritional content & $\begin{array}{c}\text { Fresh solid palm } \\
\text { oil }\end{array}$ & BSF larvae & Conversion (\%) \\
\hline Dry matter (\%) & 88.98 & 89.12 & 0.16 \\
\hline Energy kcal/kg & 3336.6 & 4773.2 & 43.06 \\
\hline Crude protein (\%) & 13.55 & 29.05 & 114.39 \\
\hline Crude fat (\%) & 12.46 & 33.72 & 170.63 \\
\hline Crude fiber (\%) & 15.47 & 11.49 & -25.73 \\
\hline Ash (\%) & 20.46 & 11.94 & -41.64 \\
\hline
\end{tabular}

The examination of the nutritional content of BSF larvae grown on solid palm oil media is presented in Table 4 and compared with BSF larvae produced on various other growing media.

Table 4. Results of BSF proximate analysis on various growing media.

\begin{tabular}{|l|c|c|c|c|c|c|}
\hline \multirow{2}{*}{$\begin{array}{c}\text { Nutritional } \\
\text { content }\end{array}$} & \multirow{2}{*}{$\begin{array}{c}\text { Solid } \\
\text { Palm oil }\end{array}$} & \multicolumn{5}{|c|}{ Various Growth Media } \\
\cline { 3 - 7 } & & $\begin{array}{c}\text { Palm kernel } \\
\text { cake }\end{array}$ & $\begin{array}{c}\text { Fermented } \\
\text { rice bran }\end{array}$ & $\begin{array}{c}\text { Fruit } \\
\text { waste }\end{array}$ & $\begin{array}{c}\text { Tofu } \\
\text { dregs }\end{array}$ & $\begin{array}{c}\text { Fermented fruit waste } \\
\text { and water hyacinth }\end{array}$ \\
\hline Dry Matter \% & 89.12 & 36.28 & & 96.69 & 96.49 & 89 \\
\hline Energy kcal/kg & 4773.2 & & & & & 2939.64 \\
\hline Crude Protein \% & 29.05 & $\begin{array}{c}47.56 \\
49.28^{*}\end{array}$ & 44.82 & 46.70 & 42.80 & 35.5 \\
\hline Crude Fat \% & 33.72 & $\begin{array}{c}19.80 \\
2.41^{*}\end{array}$ & 21.62 & 21.16 & 22.54 & 12 \\
\hline Crude Fiber \% & 11.49 & $\left.7.34^{*}\right)$ & & 13 & 22.03 & 7 \\
\hline Ash \% & 11.94 & 9.71 & 7.83 & 9.01 & 8.34 & 11 \\
\hline Referensi & & {$[13]^{*}[15]$} & {$[27]$} & {$[28]$} & {$[28]$} & {$[29]$} \\
\hline
\end{tabular}

The results of the proximate analysis of BSF larvae growing on solid media showed that crude protein was relatively high that was $29,05 \%$, although several studies showed a much higher number with range 35.5-49.28\%. Energy and crude fat are quite high $(4773.2 \mathrm{kcal} / \mathrm{kg}$ and $33.72 \%$ ) compared to the results of other studies (Table 4). Especially for crude fat is 
quite reasonable because solid palm oil still contains $1.5 \%$ CPO oil [1], so that if left in the open air, its quickly becomes rancid.

According to [20], BSF larvae contain high protein content of $37 \%-63 \%$, high fat $7 \%$ - $39 \%$, ash $9 \%-28 \%$. Variations in the nutritional content of maggot growing media will affect larvae growth [30]. The quality and quantity of larvae growth media greatly affect the nutritional content of larvae [31] and breeding ability [31-32] or the level of larvae population density [33]. In addition, the growth media composed of various combinations of materials showed the best results for the growth of BSF larvae [27-33]. Thus, the success of BSF larvae production can be seen from the protein and nutrient content in the BSF larvae growing media [34] since in meeting the body's nutritional needs, maggot needs water, protein, and fat [30].

Maggot or larvae of the black soldier fly (Hermetia illucens) is an alternative feed that meets the requirements as a protein source [35-20]. It is said that feed ingredients containing more than $19 \%$ crude protein are classified as protein sources [30] and the protein produced in this study is more than $19 \%$. Therefore, its use for animal feed, especially poultry, pigs, and fish, replaces some of the constituent feed ingredients [20].

In addition to protein, the content of BSF larvae that grow from solid palm oil has the potential as a source of energy and a source of fat, especially for poultry feed. This aligns with a result study reported by [7] that BSF larvae flour has a rich protein and fat content to strengthen its potential use in animal feed ingredients. Similarly, [36] said that BSF is considered a source of energy and an excellent source of amino acids for broilers with more efficient digestion of nutrients. However, to use it more effectively, it is recommended that the flour from the BSF larvae be defatted in poultry feed formulations. In addition, BSF larvae were reported by [21] as a source of macro minerals where calcium, phosphorus, and potassium are the most abundant macro minerals in larvae. Therefore, BSF larvae need to be developed as animal feed, a source of energy, protein, and a source of macro minerals.

The utilization of BSF larvae as animal feed ingredients is made in flour to facilitate feed formulation. The ingredients in the form of flour will make it easier to mix the various feed ingredients used to form a complete feed formula. Feed in the form of flour can be used in chickens of various ages and is easily absorbed. In addition, the flour form, feed can be made in various forms such as pellets and crumbles. Flour can be made by drying and milling where 500 grams of flour can be produced from $2 \mathrm{~kg}$ of dry maggot [37]. BSF larvae can be dried with a temperature range of $55^{\circ} \mathrm{C}-75^{\circ} \mathrm{C}$ for 18-24 hours [28]. Meanwhile, [38] carried out the process of making flour through steaming. The results show that the difference in steaming time affects the quality of maggot flour, namely the protein and fat content. The best steaming time is 25 minutes with the highest protein content value was $38.14 \%$ and the highest fat content was $15.94 \%$.

The results of various studies show that BSF larvae flour can be substituted with fish meal. According to [39] substitution of fish meal with BSF larvae flour up to $75 \%$ of the total use of fish meal in the ration can improve the performance of native chickens. Meanwhile, [40] reported that BSF larvae flour can be used as an alternative substitute fish meal in laying quail feed. Furthermore, the results of [40] showed that the substitution of fish meal with BSF larvae flour did not have a significant effect on feed consumption and feed conversion, but did have a significant effect on egg production and egg mass. Substitution of fish meal with BSF larval flour also showed a significant effect on increasing egg weight, egg yolk weight, egg white weight and Haugh unit values. As for [41] conducted a study on the substitution of MBN with BSF larvae flour, the results showed that the substitution of $50 \%$ and $100 \%$ of BSF larvae deffated flour had no significant effect on quail performance. Egg production increased by $5.82 \%$ at $50 \%$ substitution and $6.13 \%$ at $100 \%$ substitution. Thus, it shows that BSF larvae deffated flour can be used as an alternative substitution of MBM meal in quail feed. 


\section{Conclusions and suggestions}

\subsection{Conclusion}

Solid palm oil has the potential as poultry feed and an ideal medium for the growth of BSF larvae and also BSF larvae produced from solid palm oil can be used as a source of protein, fat, and energy.

\subsection{Suggestions}

The Further research is needed for its use in poultry and the quality of the product in the form of BSF larvae flour is necessary to be investigated

\section{References}

1. B. N. Utomo and E. Widjaja, J. Litbang Pertan. 23, 1 (2004)

2. E. Widjaja, B.N. Utomo, A. Firmansyah, B. Hariyanto, Saepudin, dan E. Purba, Model Pertanian Bioindustri Berbasis Integrasi Sawit-Sapi di Kabupaten Lamandau Kalimantan Tengah, Laporan Akhir Kegiatan KKP3S. Balai Besar Pengkajian dan Pengembangan Teknologi Pertanian. Bogor (2016)

3. E. Widjaja, W.G. Piliang, Iman Rahayu, B.N. Utomo, JITV 11, 1 (2006)

4. E. Widjaja and B.N. Utomo, JITV 12, 1 (2007)

5. E. Widjaja and B.N. Utomo, Prospek penggemukan sapi potong di sekitar pabrik kelapa sawit di Kalimantan Tengah. Prosiding Seminar Teknologi Peternakan dan Veteriner. Pusat Penelitian dan Pengembangan Peternakan, Bogor (2006)

6. B. N. Utomo and E. Widjaja, J. Penelit. dan Pengemb. Pertan. 31, 4 (2012)

7. M. E. Abd El-Hack et al., A comprehensive review, Agric. 10, 8 (2020)

8. A. Wardhana, War. Indones. Bull. Anim. Vet. Sci. 26, 2 (2016)

9. J. Nery, L. Gasco, S. Dabbou, and A. Schiavone, J. Insects as Food Feed 4, 3 (2018)

10. A. Dewi Apri and K. Komalasari, Feed and animal nutrition: Insect as animal feed, IOP Conf. Ser. Earth Environ. Sci. 465, 1 (2020)

11. A. R. Hakim, A. Prasetya, and H. T. B. M. Petrus, J. Pascapanen dan Bioteknol. Kelaut. dan Perikan. 12, 2 (2017)

12. A. R. Hakim, A. Prasetya, and H. T. B. Petrus, J. Perikan. Univ. Gadjah Mada 19, 1 (2017)

13. R. Rachmawati, D. Buchori, P. Hidayat, S. Hem, and M. R. Fahmi, J. Entomol. Indonesia 7, 1 (2015)

14. W. Mangunwardoyo, Aulia, S.Hem, Biota. 16 (2011)

15. R. J. M. Bokau and P. Basuki, Bungkil Inti Sawit sebagai Media Biokonversi Produksi Massal Larva Maggot dan Uji Respon Pemberian pada Ikan Nila (Oreochromis niloticus), Pros. Semin. Nas. Pengemb. Teknol. Pertan. VII (2018)

16. S. Mahfuz, Q. Shang, and X. Piao, J. Anim. Sci. Biotechnol. 12, 1 (2021)

17. Li, Q., Zheng, L., Qiu, N., Cai, H., Tomberlin, J,K. \& Yu, Z, Waste Management, 31 (2011)

18. E. I. Raharjo, Rachimi, dan M. Arief, Jurnal Ruaya 4, 1 (2016)

19. U. Masir, A. Fausiah, \& S. Sagita, Jurnal Ilmu Pertanian 5, 2 (2020)

20. K. B. Barragan-Fonseca, M. Dicke, and J. J. A. van Loon, J. Insects as Food Feed 3, 2 (2017)

21. S. Y. Chia et al., Entomol. Exp. Appl. 168, 6-7 (2020)

22. H. M. Myers, J. K. Tomberlin, B. D. Lambert, and D. Kattes, Environ. Entomol 37, 1 
(2008)

23. A.M. Kasenta, 1.N. Aini, and Riyanto, J. Inovasi Penelitian 1, 8 (2017)

24. Badan Pusat Statistik, Kabupaten Kotawaringin Barat Dalam Angka, (BPS Kabupaten Kotawaringin Barat, 2017)

25. R. Popa, T. Green, Dipterra Lcc E-Book 'Biology And Ecology of The Black Soldier Fly (Diptera Lcc, 2012)

26. J. K. Tomberlin and D. C. Sheppard, Journal of Entomological Science 37, 4 (2002)

27. A. Lestari, T. H. Wahyuni, E. Mirwandhono, and N. Ginting, Nutritional Content Using Various Culture Media 8, 3 (2020)

28. L. Purnamasari, I. Sucipto, W. Muhlison, and N. Pratiwi, Komposisi Nutrien Larva Black Soldier Fly (Hermetia illucent) Dengan Media Tumbuh, Suhu dan Waktu Pengeringan yang Berbeda, Pros.Semnas TPV (2019)

29. F. Ardiansyah, E. Susanto, and Wahyuni, J. Ilmu Produksi dan Teknol. Has. Peternak. 9, $1(2021)$

30. E. S. Rumondang, Juliwati P. Batubara, J. Abulyatama,163-171 (2019)

31. M. D. Finke, Zoo Biol. 34, 6 (2015)

32. R. Katayane, F.A, Bagau, B, Wolayan, F, R\&Imbar, M, Zootek, 34 (2014)

33. S. Rizki, P. Hartami, and E. Erlangga, Acta Aquat. Aquat. Sci. J. 4, 1 (2017)

34. A. N. Sobron, S. Titik, and S. Meidawati, J. Inov. Penelit. 1, 3 (2020)

35. R. Suciati and H. Faruq, Biosf. J. Biol. dan Pendidik. Biol. 2, 1 (2017)

36. A. Schiavone et al., J. Anim. Sci. Biotechnol. 8, 1 (2017)

37. L.N. Aini, A. Fanani dan M. S. Husein, Jurnal Inovasi Penelitian 2, 2 (2018)

38 F.M. Zulfan, Pembuatan Tepung Magot (Hermetia illucens) dengan Waktu Pengukusan yang Berbeda Terhadap Kandungan Protein Kasar dan Lemak Kasar Pengganti Tepung Ikan, in Thesis, Sekolah Pascasarjana Universitas Airlangga (Unair, 2019)

39 A.D. Putra, Pemberian Tepung Larva Black Soldier Fly (BSF) (Hermetia illucens) dalam Ransum Terhadap Performa Ayam Kampung Fase Strarter, in Skripsi, Universitas Hasanuddin Makasar (Unhas, 2020)

40 Harlystiarini, M. Rita, D.P. Astuti, I.W.T. Wibawan, Pemanfaatan Tepung Larva Black Soldier Fly (BSF) (Hermetia illucens) sebagai Sumber Protein Pengganti Tepung Ikan pada Ransum Puyuh Petelur (Cortunix japonica), in Thesis. Sekolah Pascasarjana, Institut Pertanian Bogor ( IPB, 2017)

41 S. Mawadah, W. Hermana dan Nahrowi, Jurnal Ilmu Nutrisi dan Teknologi Pakan 16, 3 (2018) 